\section{THE LATE NEWSPAPER PUFF.}

To the Editor of THE LANCET.

SrR,-The person who signs himself "Argus," has attacked me undeservedly in Tris LANCET of Saturday, the 12th, insinuating that I pay for occasional notices of my skill in the Weekly Dispatgh. Such is not the fact-and I beg, through your valuable and able journal, to give the most indignant and unqualified contradiction to every word of so unjust an accusation. If "Argus" will refer to that paper, he will find the first physicians and surgeons named there, at various periods, in a similar way; therefore his object in selecting me for remark, amongst the great and the many, I can only attribute to some sinister and selfish view.

The editor of the Dispatch, in recommending me, may have done so from the best feelings, as I have attended a part of his family. Finally, if "Argus" wishes for further explanation, he can refer to the Dispatch, more especially the last number. I am, sir, your obedient servant,

\section{A. B. Chisholm.}

\section{EFFECTS OF PRUSSIC ACID.}

To the Editor of $\mathrm{TH}$ : LANCET.

SxR,-Dr. Letheby's report of the late cases of poisoning by prussic acid, brings to my recollection a circumstance which, al though relating to an animal, bears a very remarkable analogy to one of the points connected with the unfortunate young persons who came under his examination.

A young cat having lost its mistress, (deceased,) became very uneasy, crying about the house and garden in a most piteous manner, refusing its ordinary food, declining to sleep in its accustomed place, and at last becorning so excited that it was an act of merey, as well as of prudence, to put it out of its misery.

Having with difficulty enticed it with some milk, I poured about a drachm of Scheele's acid on its nose and mouth; I watched the results with some interest, attention having been lately so trongly exeited on the subject. The poor thing at first appeared stupefied; in about ten or fifteen seconds it staggered, calmly stretched itself at full length, and expired without a struggle, or noise. What $I$ the more particularly wished to observe was the " expiratory shriek," and I was the more astonished, as I had never before seen death take place in animals from the effects of prussic acid, without violent struggling and one or more sereams: I think we may infer that no screams were made by the unfortunate couple in the cases above alluded to, as two violent shrieks, either together, or immediately succeeding cach other, would have attracted the attention of the inmates of the house.

It is very ticklish ground to draw any analogy between the mental emotions of a cat and the mental emotions of two human beings; yet, may not the state of mental excitement have tended to produce the results noted? In the case of the cat, it was not mere instinctive regard for kindness, but a positive attachment to its mistress, for it refused the same favours from other hands. Disaupointed in its attachment, there resulted the mental condition above described. Disappointment in their attachment no doubt produced a state of mental excitement which ended so unfortunately to the young couple. A specious hypothesis might easily be drawn up to account for the result.

I would only offer these ideas as a suggestion. But the collection of facts would tend materially to clear up the present mist that hangs orer the action of this fearful poison.

I am, sir, your obedient servant,

Maida Hill, Dec. 20, 1844. Geo. L. BLytr.

\section{THE ROYAL COLLEGE OF SURGEONS.}

To the Editor of ThE LANCET.

Sir,-When I have, on various occasions, visited the metropolis, it has been my custom to spend three or four hours in the museum of the Royal College of Surgeons, and until my present visit, I had been invariably accustomed to see a hall porter in attendance.

Is it true, as I have been informed, that his services have been dispensed with, in that capacity, because of the expense of a uniform?

Can this be possible? or is it, that he is elsewhere engaged, in an avocation better suited for a regular practitioner? If so, tell the powers that be, Mr. Editor, that it is a niggardly parsimony, and a very discreditable means of economising the charges of management.

I am, sir, yours very respectfully,

London, Dec. 24, 1844

\section{THE GOVER NMENT MEDICAL BILL.}

To the Editor of THE LANCET

SrR,-When I first perused Sir James Graham's Bill, it scarcely seemed credible, that it should have been proposed to the faculty by any statesman, and after carefully examining every clause, astonishment seemed to absorb all other impressions at Sir James Graham's tendering to the medical profession, for their governance, a "Council of Health and Medical Education," without a vestige of the representative principle. It is not improbable, that it would have been found difficult to have induced any other member of the Commons' house to offer so unconditional an insult to any section of society; yet this Bill, if it were enacted into a law, would place the general practitioner in direct competition with empirics.

What arguments can this statesman propose, for placing the profession of medicine under an arbitrary and irresponsible government, and the "Queen's Privy Council " retaining the power to dismiss any member of the "Council of Health and Medical Education," who might prove refractory, and appoint another of a more docile and obsequious temperament. 'The ordinary reasons, urged by statesmen of arbitrary and exclusive principles, in opposition to the application of the electoral franchise and other civil rights, have been, the defective state of the education and the absence of general information among the people, and therefore their unfitness to exercise so important a trust; but by what plausible sophistry, or propositions, and subtle deductions, he will apply them to the members who compose the faculty of medicine, in the United Kingdom, time can only develop. Sir James assisted in enfranchising the ten-pound householder in our boroughs, and yet, at one "fell swoop," he intends excluding the whole profession from the exercise of the elective franchise, in the formation of the governing power which is to control its interests ; thus, in the scale of society degrading them beneath the municipal elector of a borough town; and this affront will equally apply to the medical and surgical officers of our magnificent provincial hospitals, and other public medical institutions; who, in point of talent, education, and surgical and medical ability, are perfectly equal to the rapacious and unserupulous adviser's of the chief secretary for the home department.

In reference to the general practitioner, a severer and a bitterer doom awaits him.

It always appeared to me a principle co-eternal with trath, that a legislatrve body should exist for the general good; and that the honours and emoluments possessed by the individuals composing it shonld be the result of the faithful and honest performance of their functions, as instanced by the prosperity and happiness of the governed; but the "Medical Bill" will arm the legislative body with authority and power, calculated to originate in their breasts pride, tyranny, avarice, and other baleful passions, to which, under certain circumstances, the human heart is but too susceptible; whilst, on the cther hand, it will introduce in to the profession of medicine, a cringing, obsequious, and temporizing spirit; as a substitute for those of independence and liberty.

Certain resolutions, adopted at a recent " extraordinary meeting" of the Royal College of Physicians, Edinburgh, approve the "principles and leading details" of the bill. This might reasonably have been anticipated, because that institution is one of those venerable antiquities which possess all the inherent bad and contaminating influences of the unreformed corporations. The character of our profession is unobtrusive, retiring, and meditative. Yet, upon some future public occasion, Sir James and his party will probably discover there have been at work private influences, which have produced a reaction that bas gained for them but little respect or admiration.

It was with sincere pleasure I read Dr. Webster's letter, (President of the British Medical Association,) brought forward at the "special general meeting of the Provincial Medical aud Surgical Association, held at Derbr, on Norember 14th, and I fully concur in the views and opinions so justly and forcibly expressed by that gentleman, and it appears palpable, from the disposition and aims of the colleges of Physicians, Edinburgh, and Surgeons, London, and others, that unless the general practitioners consolidate themselves into a corporation or union, or college of medicine and surgery, they will lose " caste," and be seriously deteriorated in the estimation of society.

There was a day when Sir James Graham could not have been induced to have taken the step he has done. His motives are best known to himself. A few years ago he was amongst the most strenuous advocates for the maintenance of the rights and liberties of her majesty's subjects ; his present official life is diametrically opposed to his former one; and his chief solicitude seems to be, a persevering determination to exhibit his penitence and this 
change which has taken place in his political sentiments to the "Queen's privy council," and their friends and allies, with the intention of being received amongst them on confidential and cordial terms. I am, your obedient servant,

RoBT. HoW ARD

Member of the Provincial Medical

Hebden Bridge, Dec. 18th, 1844 . and Surgical Association.

\section{THE LONDON HOSPITAL.}

To the Editor of THE LANCET.

Sir,-At a time when questions involving the interests of the medical community at large are under consideration, $I$ am unwilling to occupy your valuable space with the subject of local grievances. Your journal, however, is the only medium through which curtain "hole and corner" proceedings at the London Hospital can obtain the publicity which they merit, and I shall therefore feel obliged by your inserting this communication.

The office of house-surgeon at the hospital just alluded to, has always been filled by a senior-dresser, who, having previously assisted as junior for six months, is well qualified to discharge the various functions which devolve upon him as resident surgical attendant. So effectively, indeed, have these functions been discharged by the "senior-dressers," that it is the concurrent testimony of the surgeons that a serious mishap or mal-praxis has never been known to occur under this régime. The advantage of this system to the students has been, that the responsibility of their position has given them a degree of confidence, an aptitude of decision, and a facility in acting on such decision, which they could not otherwise have acquired, and which has been of infinite service to them in their after career. It is this, in fact, which has been the sole inducement to pupils to enter at this institution, the school, in other respects, presenting no attraction whatever.

Now, sir, the house-committee, vested with despotic power, have determined to do away with a system fraught with so many practical advantages, and, despite the remonstrances of both surgeons and pupils, have acted on such determination. The unfortunate dressers are turned to the right-about, permitted to attend only to such patients as present themselves during the day, at night being excluded from the hospital, and thus prevented from seeing the many important cases which are brought in during that season. In defence of the house-committee's conduct it may be urged, that it is their duty to do what they consider most conducive to the public interest. In answer to this, I would observe, that the future house-surgeonships are not of necessity to be filled by "qualified men," the posts being open, not merely to those who have passed their examinations, but also to pupils, to men, consequently equally liable with their predecessors to the irregularities and propensities of the race. Again, admitting that the house-committee have the right to effect any changes that may seem fit to them, such changes cannot lawfully be made to affect students previously on the list, who have paid for the advantages of the dressership as then constituted, and cannot in justice be defrauded of what to them are "rights." It is true, the surgeons have offered to return their money to those who are dissatisfied, but the liberality of such offer becomes very questionable, when it is considered that the returned money would afford but a sorry compensation for the loss of time.

In making the above remarks, $I$ have been actuated by a sincere attachment to the institution in question, and by a conviction, that the utility of such institutions in general, consists, not merely in affording direct relief to suffering humanity, but in indirectly diffusing such relief far and wide, by sending forth to the world sound practical men.-I have the honour to be, sir, your obedient servant,

REDRESS.

\section{ON THE EMPLOYMENT OF OIL OF TURPENTINE IN YELLOW FEVER.}

To the Editor of THE LANCET.

SrR,-The Lancet being extensively circulated among the medical officers of her Majesty's Navy, I am induced to call your attention to a " most important discovery in medicine," which appears to have escaped your notice. I allude to the alleged cure of yellow fever with oil of turpentine, administered by Dr. King, deputy inspector, late of the Naval Hospital, Bermuda, first proclaimed in his official report, and since so pompously announced in the Hampshire Telegraph, as to cause doubts to arise, whether the paragraph is to be regarded as an advertisement, or a piece of irony. The use of oil of turpentine, in the fevers of warm cli. mates, as well as of our own, is well known; and has been strongly recommended by various authors; but it has never ranked very high as a remedy. According to the account of Dr. King, who gave it from the very commencement of the disease, it acted like a charm.

Few, perhaps will be disposed to follow his example, by exhibiting so powerful a stimulant in the high excitement of fever, without some other proof of its utility than bare assertion. "This talented surgeon," however, "had closely studied the causes of the late epidemic at Bermuda, and had successfully applied an approved mode of treatment." It therefore becomes his duty to throw aside his modest diffidence, and give the uninitiated some account of the fever in question-the mode of administration and physiological action of the medicine.

Some intelligent surgeons, who were at Bermuda during the prevalence of the fever, assert that it bore no resemblance to the more severe forms of fever in the West Indies; that it was a simple synochus, which readily yielded to the ordinary antiphlogistic treatment, and that the great mortality among the seamen and soldiers arose from dysentery. Let us therefore hope that Dr. King will also favour the world with some account of the result of his laborious studies in the case of fever, previous to his removal to Hong-Kong, "with increased rank, to complete his investigations in this particular branch of his profession." (Surgery ?) Without some such account, he may rest assured that his brother officers, who have treated fever in every clime, will not prove quite so credulous as his friend, Sir G. C., who appears to have selected him as his especial favourite. This, indeed, is so far satisfactory, as it shows that the old gentleman is at last anxious to make some compensation for what some have been so impertinent as to call his invariable "bitter hostility" towards the medical corps. Your obedient servant

London, Nov. 26, 1844.

FAIR-PLAY.

\section{THE CHARACTER AND CONDUCT OF THE COUNCIL} OF THE COLLEGE OF SURGEONS.

To the Editor of THE LANCET.

SIR,-I crave permission again to call the attention of the medical world to the very serious imputations which rest upon the character and conduct of the council of the College of Surgeonsimputations which, I have no hesitation in saying, are as disgraceful to the council as they are dishonouring to the profession.

Between Messrs. Lawrence and Stanley, on the one hand, and the two members of the council whom Mr. Gossett did not name, on the other, there is either a breach of trust, or a lie. Can the council think it unimportant whether or not such a charge remains unrefuted? If the charges be false, let the gross indiscretion, to call it by as light a name as possible, of Mr. Gossett be shewn, or, at least, let him be called upon to name the authority on which he brings such a grave charge as that of a breach of trust, for it is no less, against the council; whereas, if the charge be true, then let the two of the council affected by it be held up to the ridicule and scorn which they merit. But for my part, I have no doubt that the charge is true. Besides the open way in which it was made, Mr. Gossett's character as a man of honour and a gentleman is too well known for us to believe that he would hazard such a charge without the clearest and most indisputable evidence. Then let us know whether it is Messrs. Lawrence and Stanley who have violated a solemn engagement, or whether two of the council have knowingly and meanly asserted that which is false. Above all, let Mr. Gossett come forward and name the two gentlemen who stated that there was such an agreement among the council, and perhaps from them we shall obtain a distinct arowal or disavowal of the charge, so that we may know for certain which are the two of the council who have so utterly disgraced themselves and the profession.

This is not a matter, Sir, in which the personal and individual reputation of the council is alone concerned, neither can it be a personal one between Mr. Gossett and Messrs. Lawrence and Stauley; but it is a matter in which the fellows of the College more especially, and the profession generally, are deeply and individually concerned. It matters not whether Mr. Gossett thinks himself to have been injured by this dirty intrigue; it matters not whether any one, or no one, has been damaged by the paltry manceurre. It is the character of the profession which is at stake, and which cannot but be materially degraded if some refutation, or explanation at least, be not drawn from these taciturn gentlemen. Surely, Sir, it cannot be that the whole of the council are so lost to all feeling of honour, as to be careless as to the repudiation of so disgraceful a transaction? Has not a Guthrie imbibed enough of the chivalrous feeling in common among the gallant soldiers of whom he was once the companion and is now 